\title{
HVMANITAS
}

\section{Personal, paternal, patriotic: the threefold sacrifice of Iphigenia in Euripides' Iphigenia in Aulis}

\author{
Autor(es): $\quad$ Bacalexi, Dina \\ Publicado por: Imprensa da Universidade de Coimbra \\ URL \\ persistente: \\ URI:http://hdl.handle.net/10316.2/40818 \\ DOI: $\quad$ DOl:https://doi.org/10.14195/2183-1718_68_3
}

Accessed : $\quad$ 26-Apr-2023 04:55:17

A navegação consulta e descarregamento dos títulos inseridos nas Bibliotecas Digitais UC Digitalis, UC Pombalina e UC Impactum, pressupõem a aceitação plena e sem reservas dos Termos e Condições de Uso destas Bibliotecas Digitais, disponíveis em https://digitalis.uc.pt/pt-pt/termos.

Conforme exposto nos referidos Termos e Condições de Uso, o descarregamento de títulos de acesso restrito requer uma licença válida de autorização devendo o utilizador aceder ao(s) documento(s) a partir de um endereço de IP da instituição detentora da supramencionada licença.

Ao utilizador é apenas permitido o descarregamento para uso pessoal, pelo que o emprego do(s) título(s) descarregado(s) para outro fim, designadamente comercial, carece de autorização do respetivo autor ou editor da obra.

Na medida em que todas as obras da UC Digitalis se encontram protegidas pelo Código do Direito de Autor e Direitos Conexos e demais legislação aplicável, toda a cópia, parcial ou total, deste documento, nos casos em que é legalmente admitida, deverá conter ou fazer-se acompanhar por este aviso.

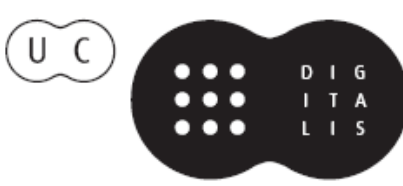




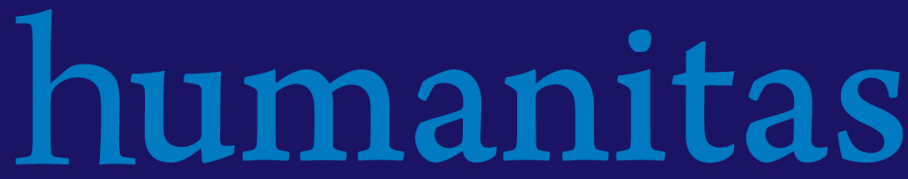

\section{Vol. LXVIII \\ 2016}

IMPRENSA DA UNIVERSIDADE DE COIMBRA

COIMBRA UNIVERSITY PRESS 


\title{
Personal, Paternal, Patriotic: THE THREEFOLD SACRIFICE OF IPHIGENIA IN EURIPIDES' IPHIGENIA IN AULIS
}

\author{
Dina BaCAleXI \\ Centre National de la Recherche Scientifique \\ bacalexi@vjf.cnrs.fr
}

Artigo recebido a 30-05-2016 e aprovado a 01-09-2016

\begin{abstract}
In the $I A$, Iphigenia accepts to be sacrificed. This voluntary sacrifice must be interpreted as a result of her threefold motivation: personal, love for life; paternal, love for her father Agamemnon, the leader of the Greek army which is about to sail to Troy; and patriotic, love for her country, the great Hellas, whose dignity and freedom Agamemnon and the army intend to defend. These three motives are interconnected and should not be considered separately. This is the principal Euripidean innovation with regard to the mythical and Aeshylean tradition of Iphigenia's sacrifice. It allows us to reconsider the Aristotelian criticism concerning Iphigenia's change of mind, and to restore the unity of her character.
\end{abstract}

Keywords: Euripides, Iphigenia, sacrifice, father, patriotism

There is a literary and mostly Euripidean motif, self-sacrifice; a context, the imminent Trojan war; men and women aiming at the right thing to do according to their status in the right place and at the right time; a young man, Achilles, and a young girl, Iphigenia, who are supposed to be married; a chorus of strangers, women of Chalkis, visiting Aulis and assisting at the events. The last of the extant Euripidean plays provides reversal, emotion, "patriotic" speeches. But above all, it provokes pity and admiration, and raises many questions about the very value of life, death, sacrifice, about the willing or unwilling offer of one's self to the cause of the many. If there is 
one play where all Euripidean themes are exposed in the clearest manner, this play is undoubtedly the $I A$.

The majority of the interpretations of Iphigenia's sacrifice only focus on one main aspect concerning her motivation and volte face: the patriotic/ Panhellenic, the personal one (desire to be praised, to control her own destiny, to surpass the ordinary female standards etc.) or the "paternal" one. Our aim in the present article is to re-examine Iphigenia's sacrifice, in order to point out its threefold character and to study Euripides' reflection within the framework of a global quest for new standards of nobility.

As a daughter and a young girl, it is quite natural for Iphigenia to be influenced by her parents' opinion; but it appears less natural that a girl prefers the paternal to the maternal motivation and arguments. As a maiden and a princess, Iphigenia aspires to the preservation of her high social status, and to the praise offered by her household and relations; these aspirations could be fulfilled through her marriage to Achilles; yet, like the other Euripidean maidens, she realizes that this traditional solution would not guarantee any happiness or glory. Iphigenia claims a better life, and therefore rejects the traditional female destiny; she accepts dying because she cannot bear the thought of a mediocre life. This is the "personal" aspect of her sacrifice. The third aspect, the more obvious one, is the patriotic or Panhellenic. As a Greek, Iphigenia really wants the Greek army to sail to Troy and win the war; but, as a woman, her only contribution to this war is to repeat her father's patriotic arguments, and to become a mouthpiece of his cause, which she completely embraces. Through her choice, she symbolically accompanies her father during his Trojan expedition. Her patriotic sacrifice is the only way to be a part of her father's plan.

Our purpose is to examine whether or not Iphigenia, the last victim, reminds us of all the previous ones, embodying the traits of every other Euripidean victim in a unique character.

\section{Iphigenia's past}

Before Iphigenia appears on stage, what do we know about her? Almost everything, in other words almost nothing. No one is supposed to ignore her legendary past, which is a part of the epic tradition (Cypria ${ }^{1}$,

${ }^{1}$ One can find a synopsis of the traditional version of the Cypria in Proclus, Chrest. 1, 135-43. López Férez 2014: 164-175 provides a comprehensive survey of Iphigenia's mythical past and its influence on Euripides, with an updated bibliography. 
Iliad ${ }^{2}$ ). There are at least two previous Iphigenia-plays, by Aeschylus and Sophocles. The latter seems to give a place to Ulysses, who is not on stage in the $I A$, in order to focus on Iphigenia's marriage and to present some thematic similarities with Philoctetes ${ }^{3}$. She is already known as the heroine of Euripides' IT, the priestess of Artemis in charge of the consecration of the Greek victims to be sacrificed according to the laws of the "barbaric" Tauris (IT 30-41). The traditional version of her myth includes her sacrifice to Artemis and substitution by a hind thanks to the goddess' intervention (e.g. in IT 25-30), although the Aeshylean version does not mention any substitution. In Aeschylus' Agamemnon, Iphigenia's sacrifice is referred to as a necessity $(A g$. 218); nevertheless,

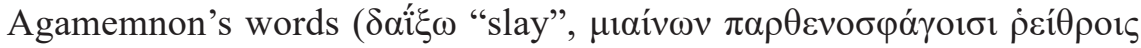

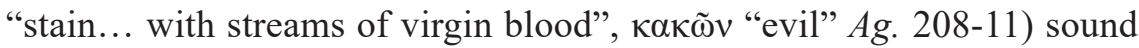
clearly as evidence of a criminal action: Agamemnon recognizes it, but on no account is he refusing this sacrifice. There is "no alternative" for him. ${ }^{4}$ Aeschylus' audience assists indirectly (through its description in the Parodos of the play) at this sacrifice: the focus is on horror and violence (228-47), instead of nobility and abnegation.

The most important thing about this sacrifice is Artemis' wrath because of Agamemnon's fault (one version) or Artemis' demand because

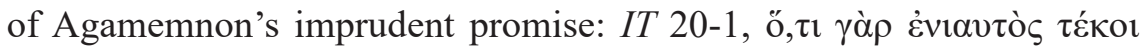

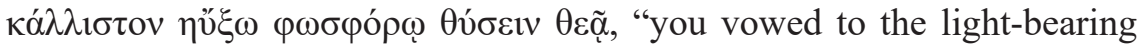
goddess that you would sacrifice the fairest thing the year brought forth"

${ }^{2}$ Il. 9, 142-8 and 283-90. Agamemnon's daughter is called 'I $\varphi$ tóv $\alpha \sigma \sigma \alpha$. Crespo Alcalá 2002: 86-88 discusses the issue of the name. 'I $\varphi$ ióv $\alpha \sigma \sigma \alpha$ in Homer is the third daughter of Agamemnon (one of them, without clarifying which one), is promised to Achilles, in order to return to the battlefield. Some scholars identify 'I $\varphi$ ióv $\alpha \sigma \sigma \alpha$ as Iphigenia. But Homer makes no explicit reference to the sacrifice of Agamemnon's daughter. Moreover, this identification is not instrumental in the study of Euripides' Iphigenia as a dramatic character.

${ }^{3}$ Michelakis 2006: 23-26 on the past of the "best-known sacrificial victim of Greek mythology", 26-29 on innovation. Cf. also Rehm 1994: 175 n.33.

${ }^{4}$ Denniston-Page 1979: XXIV and 87. Or, to put it differently, Agamemnon has, indeed, two "bad" alternatives, and makes, indeed, "the better choice": Nussbaum 1986: 25-50 underlines "the tragic power of circumstances over human goodness" and discusses the "moral" and "practical" conflict in Aeschylus, including the philosophical arguments of J.-P. Sartre, R. M. Hare and I. Kant.

${ }^{5}$ Text and translation of the IT: Kovacs 1999. 
(a different version) ${ }^{6}$. What is new in the $I A$ is the absence of reference either to the goddess' wrath, or to the king's guilt: what we do know is that Agamemnon has to sacrifice his daughter to Artemis according to Calchas' prophecy. If one ignores Iphigenia's legendary past, one also ignores why she must die. This Euripidean innovation minimizes the divine aspect of the sacrifice ${ }^{7}$, in order to emphasize the human one. The Prologue of $I A$ is a simple announcement of the prophecy, without any reference to explicit orders. The "traditional" elements are hardly recognizable. It is as if the Aeschylean necessity or violence have disappeared, as if the order to sacrifice Iphigenia were a mere invention of Calchas, not a divine punishment:

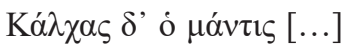

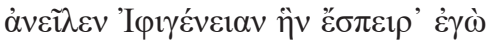

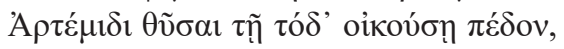

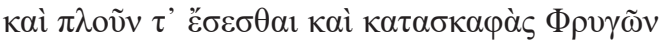

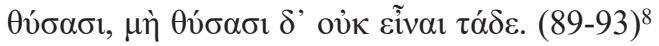

"Calchas the prophet foretold that we must sacrifice Iphigenia, my daughter, to Artemis who dwells in this region: if we sacrificed her we would be able to sail and overthrow the Phrygians, but otherwise not".

The verb $\sigma \pi \varepsilon i ́ p \omega$, Agamemnon's reference to family ties, is a usual term for descendants ${ }^{9}$; but in this very context it would mean more than the simple fact that Agamemnon is Iphigenia's father: it can be interpreted as

${ }^{6}$ Other versions of the wrath: Agamemnon's boast to be a hunter who surpasses Artemis; his father Atreus' promise to sacrifice his best lamb to her, a promise he did not honor when a golden lamb appeared to him (the goddess punished the descendant).

${ }^{7}$ The comparison with $I T$ gives the opportunity to examine what is usually called a "ritual interpretation" of $I A$. Tzanetou 1999-2000: 200-201 argues that Orestes' "near-sacrifice" in IT mirrors her sister's "near-sacrifice" in $I A$ and that the "averted sacrifice" (Iphigenia's substitution by a hind) "is routinely associated with girls' rites of passage focused around Artemis", namely the Brauronian 'A $\rho \tau \varepsilon i \tilde{\alpha}$. The more interesting point in this interpretation is the inversion of the chronological order: in order to conceive an unusual Iphigenia, a near-married and near-sacrificed but thoroughly conscious of her mission as "the benefactor of Hellas" (1446), Euripides first refers to the traditional legendary evidence (IT) and then subverts the legend by introducing a new element, namely Iphigenia's will to die $(I A)$. The change is radical, but it has already been prepared.

${ }^{8}$ Text and translation of the $I A$ : Kovacs 2002.

${ }_{9} L S J$ s.v. $\sigma \pi \varepsilon i p \omega:$ "engender, beget offspring", oi $\sigma \pi \varepsilon i ́ p \alpha \nu \tau \varepsilon \zeta$ are "the parents", passive sense: "born, begotten"; "sow" as a term of procreation; the example cited is Eur. Ph. 18,

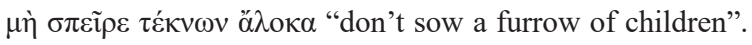


an expression of the very special, physical and indestructible bond between father and daughter. Iphigenia is Agamemnon's "seed". If he sacrifices her, there will probably be no other "seed" like her, even though he has two more children, including a boy, Orestes.

One is also supposed to know Iphigenia's story among the Taurians. She relates her near sacrifice in the Prologue of the IT, lamenting on her "ill-starred fate" $(\delta v \sigma \delta \alpha i ́ \mu \omega v \delta \alpha i ́ \mu \omega v, 203-4)$, longing for revenge on Menelaus and Helen (354-8), and recalling Agamemnon's treachery (371), namely her marriage to Achilles, without blaming Artemis, because, according to her, "no god is wicked" (391). Almost all of those different versions of Iphigenia's legend are well known. Therefore, in the $I A$, an innovation is expected - one which is necessary, in order to stimulate the audience's interest. This innovation must be as powerful as the impact of the legend. Not a disruptive one, because the audience must recognize the legendary Iphigenia; yet Euripides must (re)create his Iphigenia giving her a "second life" on stage.

\section{The "personal" reasons to die.}

Before Iphigenia appears on stage, we know about her father's change of mind (the second letter to Clytemnestra, 107-9) ${ }^{10}$ and we see Menelaus expecting Iphigenia's arrival "from Argos to the army" (328). When he discovers that Iphigenia will probably never come to Aulis, he is furious and blames his brother's "unsteady mind" (334) and "devious thoughts" $(332)^{11}$. The heroine's arrival is also expected by the audience, so there is no actual suspense: Iphigenia is on the point of arriving at Aulis. Euripides now

${ }^{10}$ Luschnig 1988 : 6-11 provides a comprehensive analysis of the Prologue, focusing on Agamemnon's aporia, on his status as chief of the army and his relationship with his brother Menelaus.

${ }^{11}$ According to Kovacs 2002: 199 n.12, "the rest of the episode [i.e. 335-441] has been considerably altered by the Reviser [...]. The plot requires only that Agamemnon resign himself to sacrificing his daughter and learn of her arrival in Aulis". A "selfish" and "inconsistent" Agamemnon would be interesting to examine, but our study will be limited to the Messenger's lines (415-439), which focus on Iphigenia. Even though the text has probably been altered or interpolated, it is necessary for the dramatic economy to announce Iphigenia's venue at this particular moment of the play, in order to stop the brothers' quarrel and prepare the arrival of the future victim. 
introduces his first innovation: a praise of the princess by the Messenger, where almost every word is deliberately ambiguous:

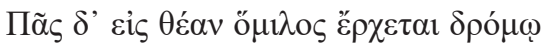

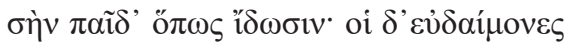

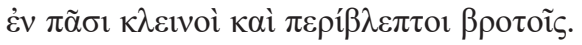

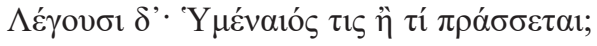

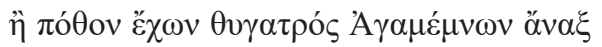

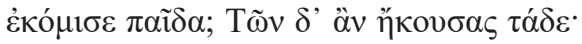

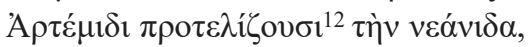

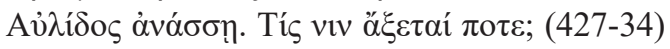

"The whole throng came running to see your daughter; the fortunate are famous and the object of any mortal gaze. They are saying: 'is a marriage taking place, or what is going on? Has lord Agamemnon brought his daughter here because he missed her?' From others you would hear this: 'they are performing the maiden's consecration to Artemis, the mistress of Aulis. Who is going to make her his wife?"”

This announcement focuses on the admiring gaze of the assistance on

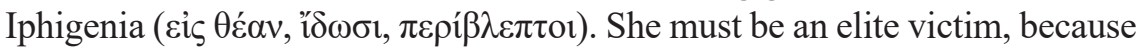
she is presented as an impressive young girl ${ }^{13}$. What is at stake here is her

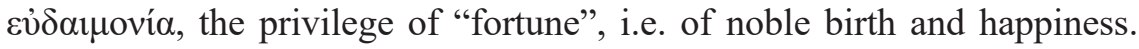
Iphigenia has a role to assume in order to justify her $\kappa \lambda \varepsilon \dot{0}$ s. Perhaps is she prepared to be married or to be "consecrated" to Artemis. The use of the ritual term is ironic: the same ritual is performed either before a marriage or a sacrifice; Artemis as a virgin goddess protects young girls; Artemis as a huntress demands noble victims. The passage stresses the double perspective of being the best bride and the best victim at the same time ${ }^{14}$.

${ }^{12}$ Seaford 1987: 108-109, 125 and n.187 on $\pi \rho 0 \tau \varepsilon \dot{\lambda} \varepsilon 1 \alpha$ associated with marriage, and on its Euripidean ironic use, "more explicit" than the Aeschylean one.

${ }^{13}$ Seaford 1987: 108, 112: Iphigenia represents the "two forms of substitute death (of a mythical maiden, of a sacrificial animal)". He studies violence as a component of some marriage scenes (the Danaïds, Persephone). In the case of Iphigenia, we could add that the omnipresent army is the violent counterpart of this joyful entry of the young girl on stage.

${ }^{14}$ On marriage and sacrifice as rituals, see Foley 1985: 69. Gibert 1995: 242-243 comments on Foley's interpretation: Iphigenia "imposes on her sacrifice the interpretation as a marriage and deliberately emphasizes the happy side of that occasion". Gibert 2005: 263-264 insists that Greek marriage is a men's deal, where "the desires of women are irrelevant". Even in the case of a sacrifice compared to a marriage, it would be a fairly strange marriage 
Another interesting point in these lines highlights the relationship between Agamemnon and Iphigenia: it is the first time we hear about his "longing" ( $\pi$ ó $\theta$ o $)$ to see his daughter before his departure to the war. Echoing this desire of her father, Iphigenia will wish to accompany him to his journey to Troy:

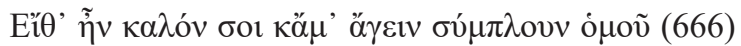

"How I wish it were proper for you to take me with you as a shipmate!"

Iphigenia's desire to be always at the same place as her father and

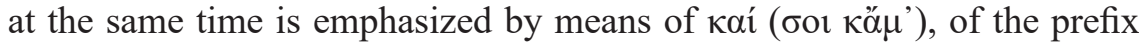
$\sigma v v-(\sigma v ́ \mu \pi \lambda o v v)$ and of $\dot{o} \mu \mathrm{ov}$, the three terms in the same line: as if the noble marriage, a delightful prospect for every young girl of her social condition, were of less importance than her strong ties to her father. The "personal" and "paternal" aspects are interwoven.

Another aspect of the desire is the erotic one. Are we to argue with Michelini that Eros is an instrumental motive for Iphigenia's self-sacrifice? ${ }^{15}$ When Michelini examines the relation between Iphigenia and her putative fiancé, Achilles, she refers to the maiden's "erotic longing for glory" in order to be "the bride of this archetypal hero" (i.e. the Achilles of the Iliad). Yet we have no textual evidence of "eroticization" of the Achilles-Iphigenia relation, only the ordinary reserve of a well-educated young girl towards her future husband (1340 "open the door, slaves, so that I may hide myself indoors"), and the shame when her father's lie about the marriage is

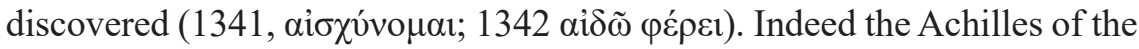
$I A$ shares few common characteristics with the Homeric one. Rather than the "archetypal hero", in the $I A$ we see above all a boaster, who pretends to be a free man and to use his spear "so far as it in [him] lies" (929-30), whose "name" will never allow Agamemnon to kill Iphigenia (947), who swears in front of Clytemnestra that "king Agamemnon shall not touch your daughter, no, not lay his fingertip on her robes" (950-1, emphasis on

where the bride, Iphigenia, makes a free choice of her future husband (Achilles or Hades). The only traditional aspect here is the final choice, the sacrifice: it corresponds exactly to what her кúpio̧ has planned for her. Although Rehm 1994 does not discuss specifically the $I A$, pointing to Foley's work on this play, it is worth noticing that the $5^{\text {th }}$-cent. practices described (11-29) fit Iphigenia's "sacrificial" marriage perfectly.

${ }^{15}$ Michelini 2000: 51-53. 
the two negative particles ov $\chi$ /ov $\delta$ in the beginning of each line) and who does not exclude the use of violence for Iphigenia's sake:

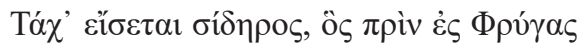

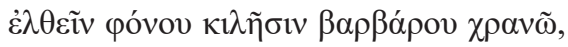

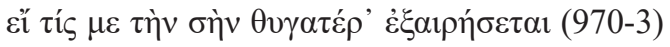

"This sword will bear me witness: even before I get to Phrygia I shall stain it with barbarian blood if someone robs me of your daughter ${ }^{16 "}$.

If Agamemnon does not yield to the supplication of his wife, Achilles wishes that Clytemnestra and therefore Iphigenia could have recourse to him (1015-6); if Clytemnestra fails, he will be here protecting her daughter (1028). Achilles is not interested in Iphigenia (he presents himself as a highly prized bridegroom, 958-9), but in his own glory.

After being confronted with the army's violence, despite the fact that he tries again to preserve his heroic character or to stimulate Clytemnestra's admiration because he has risked being "stoned to death" $(1350)^{17}$, Achilles finally abandons Iphigenia's defence: his only proposal is that Clytemnestra must "hold fast to" her daughter (1367), not let Ulysses "drag her away"

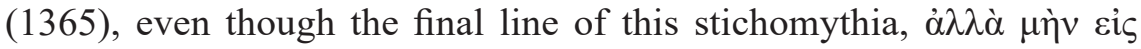

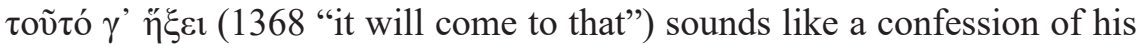
powerlessness.

Achilles is a "reasonable" character admitting his defeat. Euripides subverted the Homeric archetype: the real hero is not Achilles, but Iphigenia, and she is not in love with him, she imposes her choice on him and thus she becomes the leader of the action. In the Iphigenia-Achilles couple, the traditional male/female roles are reversed; but this is no evidence of "eroticization" of their relation. Furthermore, Iphigenia is addressing him

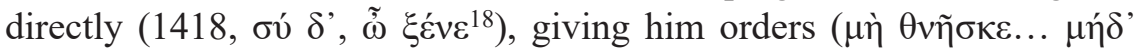

16 "Barbarian blood": the Atreides' family is from Asia Minor, a "barbaric" land (Kovacs 2002: 273, n.22 and 23). Achilles is proud of his "pure" Greek origin of Phthia in Thessaly. See Hall 1991: 176-177 for a parallel between "xenophobic" discourse in tragedy and the Athenian law courts.

${ }^{17}$ For an interesting analysis of the role of the army and of this scene in particular see Michelakis 2006: 44-46.

${ }^{18}$ Stahl 2003: 137-138 comments on $\xi \dot{\varepsilon} v o \zeta$, which he translates "my friend", in order to present Iphigenia's relationship to Achilles as a result of love or $\varphi \imath \lambda i ́ \alpha$. Kovacs translates literally "stranger"; Jouan 1983: 117 n.1 thinks that this word, which "has no equivalent 


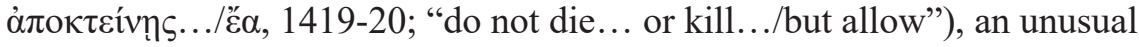
manner to express "erotic" desire or submission to a future husband. Neither Achilles who does not care for Iphigenia, nor Iphigenia, who only cares for her father, have anything to do with any aspect of erotic desire. The real couple in this play is Iphigenia and Agamemnon, not Iphigenia and Achilles. Marriage with Achilles (or marriage in general) can hardly be counted among Iphigenia's personal reasons to refuse or to accept sacrifice.

It is interesting to compare Iphigenia's first arguments against the sacrifice (1211-52) with the ones she exposes 1. 1368-1401, after her father's monologue (1255-75) justifying his decision to proceed to this sacrifice.

Like her mother, for whom the sacrifice is a personal and a family affair (cf. 1141; Clytemnestra regards it as a prejudice against her, instead of Iphigenia), Iphigenia alludes to family life, to her role as a daughter, and especially as the eldest and the most loving child (emphasis is put on

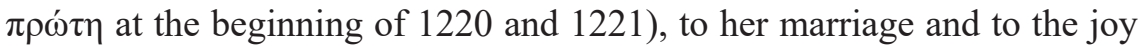
of receiving her old father into her home, in order to "repay for the toil of [her] nurture" $(1230)^{19}$. There is no allusion to public life, either to the army or to the expedition; she only alludes once to an "external" affair (i.e. neither private, nor familial), when she refuses any relation between her and the "marriage of Alexander and Helena" (1235-6). The sacrifice is limited to the nuclear family, the mother, the father and their children. There is no place for broader considerations.

On the contrary, when she decides to die, "personal", "public" and "familial" motives are interwoven. She does not want to be isolated, "a single life" (1390), and regards herself as a part of the broader family of all the Greek (1385). Nevertheless, she aims at the preservation of her (nuclear) family, because she urges her mother "not to hate" Agamemnon, referred to firstly as a father, secondly as a husband (1454). After Clytemnestra's

in French, [...] means something between 'stranger' and 'friend'". In ancient Greece, "friendship" is a result of hospitality toward strangers, an "exchange" of hospitality. But this kind of friendship concerns only men, not women (or a man and a woman), and neither Achilles nor Iphigenia have ever been hosts. In translating "my friend", Stahl, in our opinion, expresses the state of the young girl's mind, rather than a real tie between Achilles and her.

${ }^{19}$ According to Stockert 1992: 544, an echo of Agamemnon's $\pi \mathrm{o} \lambda \lambda \grave{\alpha} \mu \mathrm{o} \chi \theta \dot{\sigma} \sigma \alpha \varsigma \pi \alpha \tau \dot{\rho} \rho$, "the father who has worked so hard" (690) and who must now give his daughter to her future husband. In both passages there is a reference to the girl's education by her father (not her mother): a supplementary reason for Iphigenia to be indebted to Agamemnon, not Clytemnestra. 
violent charge against Agamemnon (1146-1208), Iphigenia's acceptance to be sacrificed could be interpreted as an attempt to reconcile her parents and thus to preserve her family.

Concerning her complete submission to Artemis' will, (1395-6), it could be either an evidence of Iphigenia's piety and resignation (a mortal is not allowed to oppose a deity), or, in a quite ironical sense, highlight the oddity of a demand whose justification remains unknown.

Like her mother later on in the play, Iphigenia appeals to morality and sentiments. She opposes her own good memory to her father's forgetfulness (1231-2), she tries to arouse his compassion for her mother's double travail (1234-5), and to revive his paternal feelings: a glance, a tender kiss (1238) is all that would remain after death.

It is worth noticing that these considerations no longer appear in her acceptance discourse. Her "moral" concerns become less "egocentric", more general: she appeals to a "just plea" (1391), implying that her decision to die for the many is the only way to achieve justice.

The final three lines of her supplication, 1250-2, are regarded as dubious. Kovacs is bracketing them. They have given rise to scholarly discussion about the question of whether Iphigenia is "mad" or not $(\mu \alpha i v \varepsilon \tau \alpha i){ }^{20}$. These lines are also supposed to be a statement against traditional heroism and

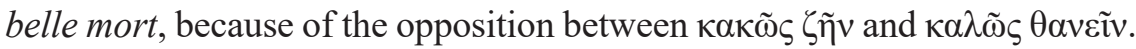
According to Jouan, these lines only intensify the dramatic tension and give more value to Iphigenia's change of mind ${ }^{21}$.

Our purpose here is not to discuss bracketing or not: because of their dramatic value, these lines could probably have been an actor's interpolation in order to increase empathy between the public and the maiden. Yet what is important, especially in 1252, is the emphasis on death, $\theta \alpha v \varepsilon i v$, at the beginning and the end of the last line of Iphigenia's monologue: it reminds us of Iphigenia's fate, introducing the question of how Euripides will manage to transform the violent Aeschylean version of the sacrifice

${ }^{20}$ Siegel 1980: 321, based on these lines, supposes that Iphigenia is "driven mad" when she chooses sacrifice instead of life. According to Funke 1964: 299, Iphigenia is

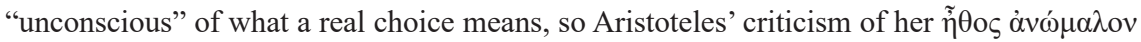
(Po. 1454a, 26-33) is justified. See also Gödde 2011: 265-268 on Iphigenia's "madness" and on the "psychological" aspects of characters.

${ }^{21}$ Jouan 1983: 147. 
into a voluntary offer ${ }^{22}$; how he will present this radical transformation of a young girl who loves life into a willing sacrificial victim who gives her life. Furthermore, the opposition between (bad) life and (good) death should be interpreted with regard to the particular context of this play: what does it mean to live or die, for a $\varphi \imath \lambda$ o $\alpha$ $\alpha \omega \rho$ (639) girl like Iphigenia? Even when she is referring to her imaginary future, she is unable to view it as independent of her father's one. She seems anxious about the mysterious "sailing" she must undertake alone, separated from her father and mother (667-70), asks no further questions when her father forbids her to do so (671), but orders him to "hurry back" from war for her own sake $(672)^{23}$. Life only makes sense if he is at her side.

\section{The "paternal" reasons to die.}

In this part we will argue that Iphigenia's "paternal" reasons are the same, no matter whether she refuses or accepts sacrifice. In both cases, she is the $\varphi \imath \lambda o \pi \alpha \dot{\tau} \omega \rho$ daughter who longs for her father's love, the one who takes her father's place in the play when Agamemnon is entangled in his own lies and tries to justify his horrible decision. Iphigenia becomes the real leader, symbolically of the army, actually of the tragic action ${ }^{24}$.

Let us first examine Agamemnon's motives for engaging the Greek army into this war (and therefore for sacrificing Iphigenia) from three different viewpoints: his own, Menelaus' and Clytemnestra's.

According to Agamemnon, in the Prologue (61-5), the reason of this "Panhellenic" war is the pact concluded between the suitors of Helen to

${ }^{22}$ Aeschylus, $A g$. 205-247. On violence and the opposition between Aeshylus' and Euripides' sacrificial narrative: Loraux 1985: 75-77; Crespo Alcalá 2002: 94-101 and 104105; Durán López 2003: 76. Foley 1982: 176 does not believe that "the violent Aeschylean scenario" can be "fully transformed by individual gestures of pity and self-sacrifice". Yet violence remains in Euripides, death is omnipresent, but "pity and self-sacrifice" give a new sense to this violence, which becomes a human affair, a matter of choice.

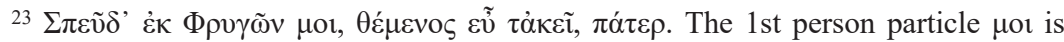
omitted in the English translation (the French one "reviens-moi" is more precise), despite its importance: the return of Agamemnon is referred to as if it were a favor or a gift reserved for Iphigenia alone.

${ }^{24}$ Felson 2001: 33-34 and n.18 comments on $\varphi \imath \lambda o \pi \alpha ́ \tau \omega \rho$ in order to emphasize the special bond between Iphigenia and her father, which "excludes Clytemnestra" and establishes an exclusive relation between the father and the daughter, leaving no place for the mother. This would be a prelude to Iphigenia's "patriotic" speech (1375-1401). 
"make a military expedition" in order to help Helen's future husband, in case of rape, to get her back "by force of the arms". Agamemnon, Menelaus and the other Greek leaders have to keep their oath, whatever the cost in human lives.

According to Menelaus, Agamemnon must remember his personal involvement in order to obtain the leadership of the Greek army, a real electoral campaign (337-42), and his longing for power and glory ( $\dot{\alpha} \rho \chi \eta$,

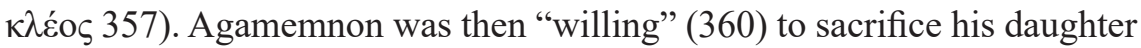
to his personal interests. After the arrival of Iphigenia at Aulis, Menelaus takes pity on his "desperate" brother (472), changes his mind (478) and advises him to "disband the expedition" (495) and save his daughter's life. But now Agamemnon presents a new motive for continuing the military process and therefore killing Iphigenia: the "necessity" according to him, (511), i.e. the "fear of the army" according to Menelaus (517) ${ }^{25}$. Neither Menelaus nor Agamemnon insists here on a "patriotic" core motive. The oath of Helen's suitors no more specifies the nationality of the enemy: the expedition should be made "whether it was a Greek or a barbarian" (65). Agamemnon exposes his patriotic arguments later on in the play (1255-75), when he has to explain why he abides by his decision despite Iphigenia's supplication and Clytemnestra's threats ${ }^{26}$.

According to Clytemnestra, Agamemnon's motive is to help Menelaus to get Helen back (1168), a "tribute" to a "bad woman" (1169). Clytemnestra

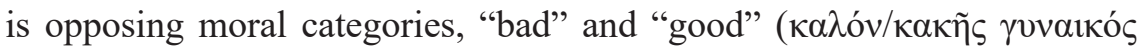
1168-9), and feelings, "love" and "hatred" ("ُ $\chi \theta 1 \sigma \tau \alpha / \varphi i ́ \lambda \tau \alpha \tau \alpha$ 1170). She aims to prove that Agamemnon's decision will entail moral condemnation: how could he prefer the military leadership and expedition (1194-5) to the life of his own child?

After Clytemnestra's interpretations of Agamemnon's motives to go to war, his arguments, despite his effort to be a responsible commander of the army and a faithful suitor of necessity, seem rather weak and unconvincing. What is at stake here is neither his personal glory, nor his piety (there is hardly any reference to religious motives here or elsewhere in the play), but his

${ }^{25}$ Siegel 1981: 262-263.

${ }^{26}$ Mellert-Hoffmann 1969: 30-31 and 33-34 insists on the instrumental patriotic motive for both Agamemnon and Menelaus, and presents Helen's rape as a "concrete" aspect of the Panhellenic cause. But the patriotic ideal cannot be the unique motive, since the oath does not necessarily imply an exclusively Greek solidarity against barbarians. 
responsibility to lead a campaign against the "barbarians" 27 . At the beginning of his monologue (1255-75), we notice that the patriotic argument is absent. Agamemnon is facing insurmountable odds: he must choose between two

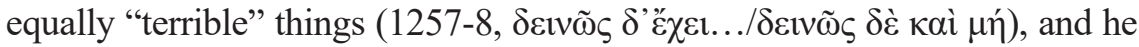
is impressed by the army's irrational power (1263) which can be used against his own children if he does not respect his promise to sail to Troy (1267-8). The patriotic motive appears at 1271, too late to be regarded as Agamemnon's principal concern. Late though this motive arrives, the leader of the Greek army puts forth here for the first time the question of Greece as a whole (not only as the country of Helen and Menelaus), of the Hellenic superiority over the barbarians, of the Hellenic pride and the Hellenic freedom:

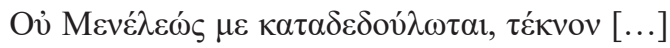

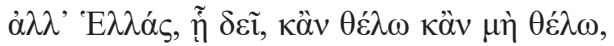

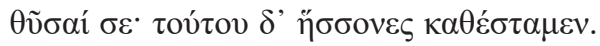

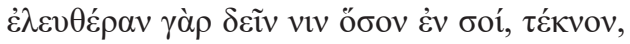

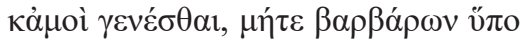

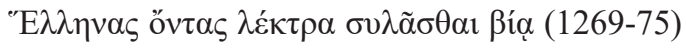

"It is not Menelaus who has enslaved me, my daughter, [...] it is Hellas. To her, I must sacrifice you, whether I will or no: she is my ruler. As far as it depends on you, my daughter, and on me, she must be free, and we Greeks must not have our wives forcibly abducted ${ }^{28}$ ".

Agamemnon exposes here for the first time his patriotic duty, as well as his difficulty to adhere to this cause: for him, the army is powerful but "foolish" and incontrollable; even though he is its supreme leader, he seems to have no influence or authority on it, to be actually "enslaved" to his fear of the soldiers under his command. But if Agamemnon is unable to endorse the commander's charge, it is necessary to find another leader, real or symbolic, replacing Agamemnon and fulfilling his mission.

${ }^{27}$ Agamemnon says that it is Calchas who ordered the sacrifice "to Artemis" (89-90), but he mentions no reason for imposing it. Menelaus repeats this (348-49). Agamemnon takes it up again, adding his fear of Ulysses (529-31), and finally he addresses his daughter referring only to Calchas' prophecy, not to the goddess' will (1262). Luschnig 1998: 2 thinks that the oracle "predicts [...] commands [and] warns".

28 Stockert 1992: 18-19 examines the value of this patriotic statement: according to him, the question is not to prove if this speech is an expression of Agamemnon's inner conviction at this very moment. What is instrumental is the public character of the statement, especially the fact that these words will strike Iphigenia's ears and contribute to her decision. 
Agamemnon leaves the stage after the end of this speech. He will never appear again. The way is now open for his "substitute" who shall be able to show a stronger will and a clearer commitment. Iphigenia's "paternal" motive sheds new light on what her father is (or is not) able to do: it is clear that his weakness will not lead the army to victory; it is also clear that no other leader (Menelaus or Achilles) is able to do so. Iphigenia will endorse the role of the leader because her father was previously meant to have it. As it is impossible for her to become a male leader, she has to die. Her "change of mind" (acceptance of the sacrifice) is in fact a "change of state": from maiden and daughter to army leader.

\section{The "patriotic" reasons to die}

Agamemnon's mourning, his changing decision (or "inconsistency") can be interpreted as a precursor of Iphigenia's reversal. The maiden turns from joy (due to her imminent marriage) to annihilation (due to the announcement of her imminent sacrifice), but later on she changes her mind and transforms a constraint into a free choice. The question of "consistency" or "inconsistency" becomes the central point of the dramatic action: a weak and rather inconsistent Agamemnon and a strong-minded and consistent Iphigenia, his exact opposite.

Agamemnon's patriotic arguments prepare this so-called Iphigenia's reversal: her "patriotic" motivations join her "personal" and "paternal" ones, because even her father, who previously refused to sacrifice her considering that the sacrifice would be an undeserved gift to Menelaus and his "wicked wife" (396-9), now explains that it is his duty to protect his country and family and to prove the Hellenic superiority over the barbarians. Agamemnon's change of mind is a piece of the dramatic economy, because it prepares the public to see a new and different Iphigenia on stage. Although we cannot be sure that Hellas will no longer be under the barbarian threat, this sacrifice will guarantee the annihilation of the threat, at least temporarily.

Iphigenia presents her new decision as a result of an intellectual process and invites her mother (and Achilles, who is watching the scene) to listen to her:

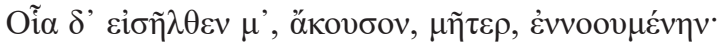

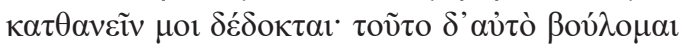

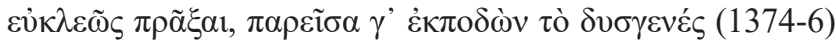


"Hear, mother, the thoughts that have come to me as I pondered. I have decided to die: my only wish is to act nobly, clearing myself from all taint of baseness".

Iphigenia no longer appeals to sentiments, or personal and familial ties. Her new reference is to her "inner reason" ( $\dot{\varepsilon} v-+v o \tilde{v} \varsigma)$, an unusual feminine reference, but a usual one for a Euripidean woman. She then invites her mother to "consider" with her (1377) the validity of the forthcoming arguments in favour of a "patriotic" sacrifice. She thus imposes a new method of decision-making, based on mature reflection, not on divine orders or "necessity". Yet it is not considered proper for young girls to make decisions: in the family context, it is the father who decides; in the public context, city or army, it is the politicians or the military commanders. Agamemnon is absent, Achilles seems rather fatalist (Ulysses is too powerful, he has too many soldiers with him and would probably take Iphigenia away, 1360-9): because there is no commander equal to the task, Iphigenia, the commander's daughter, undertakes the defence of Hellas.

Let us consider the historical context of the play ${ }^{29}$. The $I A$ is the last Euripidean play, probably remaining unfinished at the time of Euripides' death in the winter of 407-406 B.C., written in Macedonia, where the author migrated in 408 B.C. The play was performed posthumously in 405 B.C., only one year after the end of the Peloponnesian war (404 B.C.). At this very moment, a play with a violent political context in which a sacrifice, a violent act, is a means of salvation of the many, of the "Panhellenes", could offer a reason for hope, meagre though this hope may be. The adherence of the young girl to her father's patriotic cause would be a reason to believe that the "politics of love" 30 are still valuable, the solidarity ties have not been completely destroyed.

There is no evidence that Iphigenia's arguments are "empty words" 31 , that Euripides "hides" himself behind Iphigenia's character or that the play

${ }^{29}$ See Jouan 1983: 39-43, with reference to Goossens' 1962 historical interpretation (in the chapter entitled "La Grèce vue de Macédoine", 673-721). Although we agree with Goossens' political interpretation of the sacrifice as Euripides' critic of the failure of the Athenian democracy at the end of the Peloponnesian war, it would be difficult to follow him in considering Iphigenia a mere mouthpiece of Euripides.

${ }^{30}$ Foley 1982: 177.

${ }^{31}$ Funke 1964: 292. 
only reflects the author's political convictions ${ }^{32}$. Neither can we agree with the Aristotelian critic (Po. 1454a, 30) that this Iphigenia (the patriot) "has no common points with the previous one" (the loving young girl unwilling to die) ${ }^{33}$. Euripides created Iphigenia as a character and wrote his play in the particular historical context of the end of the Peloponnesian war. But the $I A$ is a tragedy, not a political discourse; Iphigenia is a fictional character, not an Athenian orator.

Iphigenia's perception of the "Panhellenic" ideal is an issue discussed by some scholars ${ }^{34}$. Iphigenia is a princess confined to her parent's palace and waiting to be married; she is not supposed to be aware of the political or military context. Yet Iphigenia, in the play, is the most $\varphi \imath \lambda o \pi \alpha ́ \tau \omega \rho$ of all Clytemnestra's and Agamemnon's children, the one who wants to be always by the side of her father, and the one who has listened to his patriotic reasons to sacrifice her. Iphigenia's "Panhellenic" vision is influenced by her father's discourse: it is fairly normal, for a daughter like her. It is also an opportunity for Euripides to underline the difference between her and

32 Said 1984: 36 regards Iphigenia's patriotic speech as "slogans", a "heritage" of the Medic wars reused in order to transform an imperialistic war into a war for freedom. Funke 1964: 292, 295, 299 thinks that Iphigenia, being an inconsistent character, only repeats her father's arguments. She is the opposite of Medea, who "knows what she is doing" when she finally decides to kill her children.

${ }^{33}$ Luschnig 1988: 108: "Euripides [...] purposely used anomaly of construction and character as a dramaturgical device"; cf. 91-110 for a comparison with plays "accused of inconsistency" (Medea, Hecabe, Heracles, Heraclidae).

${ }^{34}$ According to Bonnechere 2009: 210, the Panhellenic cause is "meaningless". The value of Iphigenia's perception of "Greece" as an ideal worth sacrificing herself for is under question. Siegel 1980: 315 opposes her "self-delusion" (Iphigenia thinks that "Greece" is a noble cause) and the reality of "ignoble causes and forces". For O'Connor Visser 1987: 123, the Panhellenic ideal is a result of Iphigenia's and Achilles' first meeting, when she "realizes that the whole Hellas is watching her and that so much depends on her". Foley 1985: 78 establishes a parallel between marriage and sacrifice, both Panhellenic rituals. Michelini 1999-2000: 55-56 quotes Isocrates Hel. 67, Paneg. 181, and Aeschines 3, 122 , insisting on the violence of the Panhellenic ideas. On the concept of "Panhellenism", the term П $\alpha v \varepsilon \dot{\lambda} \lambda \eta v \varepsilon \varsigma$, tragedy as a "Panhellenic" genre, and Panhellenism in the $I A$ : Rosenbloom 2011: 353-361 and 372-379. The comparison between the Panhellenic ideal of Iphigenia in the $I A$ and the "longing for Hellas" and "restoration of the Hellenic identity" of Iphigenia in the IT shows "the fruitfulness of Panhellenic themes as a source of emotional engagement". Cf. also Michelakis 2006: 76-78. 
her mother, who is not interested in "politics" at all ${ }^{35}$. But the daughter's arguments are more solid than her father's.

Let us consider her references to Hellas, her homeland:

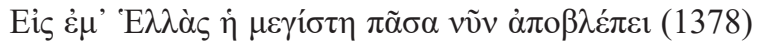

"Hellas in all its might now looks at me".

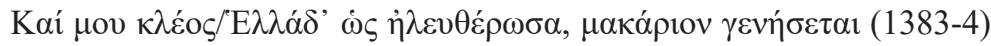

"And the fame I win for freeing Hellas will make me blessed".

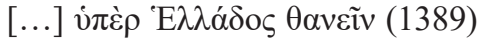

"to die on behalf of Hellas".

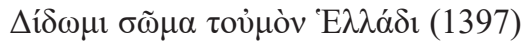

"I shall give myself to Hellas ${ }^{36 "}$.

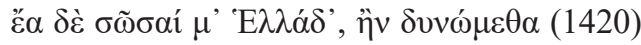

"Allow me to save Hellas if I can".

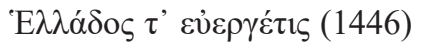

"Hellas' benefactor".

The reference to freedom (1383) echoes Agamemnon's “she [i.e. Hellas] must be free" (1272-3). The difference is that Agamemnon is "enslaved" (1269) to the freedom of Greece, an oxymoron (how can one be a slave of freedom?), while Iphigenia embodies the expectations of all Greece (1378): her free choice guarantees Greek freedom.

The reference to the salvation of Greek women (1380-3) and of Greece in general (1420) echoes Agamemnon's "we Greeks must not have our wives forcibly abducted by the barbarians" (1274-5). The difference is that Agamemnon only cares for women's abduction, while Iphigenia is presenting herself as the saviour of all Greece, including women. The salvation verb

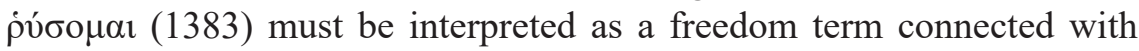

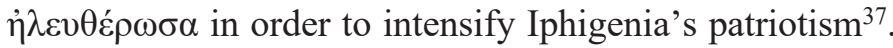

Iphigenia's war is not so different from Agamemnon's: it is a war of conquest. The difference is that Agamemnon's manly duty, as of all Greek men, is to sail to Troy, to make real war and probably to die in it. Iphigenia cannot participate in this war or accompany her father to Troy. By accepting

${ }^{35}$ Felson 2001: 33-34 and n.18.

${ }^{36}$ On Iphigenia's use of the word $\sigma \tilde{\omega} \mu \alpha$ as a "leitmotif" and an instrument either of supplication or of salvation: Stockert 1992: 543.

37 Stockert 1992: 587. 
the sacrifice, she becomes a part of the kotvóv of Greece, and of the Greek army. An unexpected glory for a woman:

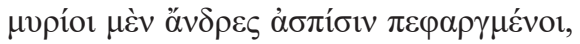

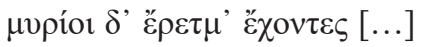

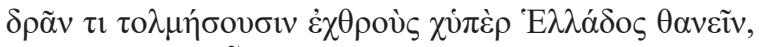

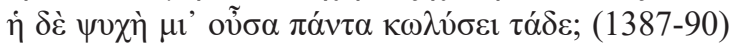

"Countless hoplites and countless rowers will dare [...] to fight bravely against the enemy and die on behalf of Hellas: shall my single life stand in the way to all this?"

This comparison between a young sacrificial victim and the soldiers who defend their homeland has appeared previously in Euripides' Phoenician women, where Menoeceus offers his life to save Thebes (Ph. 997-1014), comparing his sacrifice with the one of the Theban soldiers. Like Iphigenia, Menoeceus has patriotic motives. Like Iphigenia, he aims to participate in the war, but like her he is too young to be a soldier. His sacrifice changes him into a combatant. Her sacrifice changes her into a Greek soldier.

But there are differences between those patriotic sacrifices: firstly, Menoeceus, like every man, is destined to be a soldier at any rate, while Iphigenia becomes a "soldier" by means of her sacrifice; secondly, Menoeceus disobeys his father Creon, the king of Thebes, who refuses to sacrifice his son to his homeland, while Iphigenia obeys her father Agamemnon and dies for their common homeland, for their common $\operatorname{war}^{38}$.

The patriotic and the freedom themes are also connected with Greek superiority:

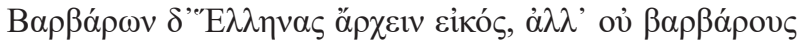

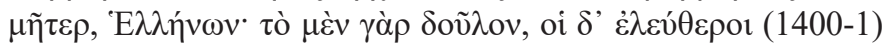

38 Stockert 1992: 34 examines the relation between youth and (self) sacrifice as a mark of $\mu \varepsilon \gamma \alpha \lambda$ o $\psi v \chi i \alpha$ (high mind). He refers to Aristotle (Rh. 1389a): young people are "ambitious for honor", "ambitious for victory", "good-minded", "confiding", "of good hope", and $\mu \varepsilon \gamma \alpha \lambda$ ó $v$ $\chi 01$ "high-minded"; "in their actions, they prefer the good to the useful". But they are also impulsive, acting under the influence of passion rather than reason: Iphigenia's sacrifice, according to this interpretation, is the result of an impulse of her heart, as well as of rational reflection and support. In our opinion, the "impulse of her heart" corresponds to her love for her father. 
"Greeks, mother, must rule over barbarians, not barbarians over Greeks: the one sort are slaves, but the other are free men".

Iphigenia praises Greek superiority but she does not intend to humiliate the barbarians. She broadens her father's argument concerning the "abduction of Greek wives" $(1265,1275)$ and refers to an ordinary Athenian reality: most barbarians are slaves, so it would be normal for a Greek princess to present them as $\operatorname{such}^{39}$. This presentation of the barbarians is undoubtedly a cliché; nevertheless, there is no reason to minimize its importance in the whole patriotic framework, which is common to Iphigenia and her father. If this argument were only an "ironic" one ${ }^{40}$, there would be no place for any term related to "intellectual" activity, like the ones Iphigenia uses in the beginning of her speech: Iphigenia really means what she says, even though she might be influenced, like any Greek, by the idea of Greek superiority, a usual pattern at the time of the play.

The culmination of Iphigenia's patriotic arguments is "you bore me for all the Greeks in common, not for yourself alone $(1386)^{41}$. This statement echoes Agamemnon regarding himself as the "ruler" of Greece (1271-2). Iphigenia believes that she is a part of a whole while her mother is only a (selfish) member of her own family. The opposition "all the Greeks"/"alone", first/last word of the line, emphasizes the distance between the mother and the daughter.

The 11. 1393-4, "better to save the life of a single man than ten thousand women", sound rather odd in a speech where a woman offers her life in order to restore the dignity of her country and to guarantee Hellenic superiority over the barbarians. Iphigenia explains why Achilles should not risk a violent confrontation with the Greek army for her sake. "A single man" more important than "a thousand women" is a cliché, but it fits in with the war context of Iphigenia's speech and of the entire play. It could also be an echo of 1169 ("a bad woman", i.e. Helen): Iphigenia refuses to be a woman for whose sake so many men jeopardize their life. Or is it a simple reference to this very man, Achilles, her putative fiancé, whose life she aims to preserve? In this case, there is an additional reason to admire her altruism. At any rate, this could not be a "misogynist" statement ${ }^{42}$.

\footnotetext{
${ }^{39}$ Hall 1989: 196-197.

40 Said 1984: 36.

${ }^{41}$ Sébillotte Cuchet 2006: 286-287 examines the "duty of the Greek mothers" to give their children to Greece. The best example is Praxithea in Euripides' Erechtheus.

42 One can find an interesting interpretation of these lines in Stockert 1992: 589.
} 


\section{Three Iphigenias in one or The unity of the character}

Let us re-examine the threefold motivation of Iphigenia, in order to answer the Aristotelian critic that the "suppliant Iphigenia has nothing to do with her later character".

Iphigenia is a young girl who loves life, but, above all, she loves her father. She first wants him to "stay at home with his children" (656), then wishes to accompany him (666) and finally, when he exposes the patriotic/ Panhellenic reasons for the Trojan expedition and her sacrifice, she accepts it. Is her life worth living without her father?

Iphigenia is a princess who will be married to "such a man", Achilles (711), her father will accomplish almost all the wedding rites, and this is the reason why he asks Clytemnestra to return to Argos (719-36). But for Iphigenia her future life as a married woman is hardly conceivable without her father (1228-30). Therefore, what is important for her is not marriage, but their common future.

Agamemnon is not an ordinary father; he is the leader of a great army. Iphigenia is impressed by the powerful and irresistible army (1338); but she is mostly concerned about her father's responsibility as a leader of this

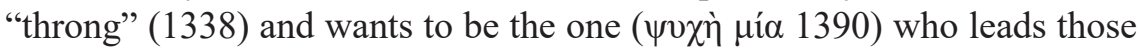

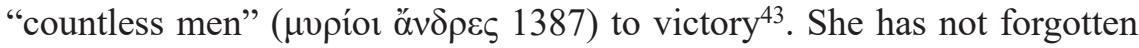
marriage or future life, she only realizes that it would be impossible for her to live if Greece were enslaved or her father humiliated. She thus makes an exchange in order to preserve glory: "that for me will be my long-lived memorial, that will be my children, my marriage, my good name" (1398-9).

Iphigenia changes her mind and accepts to give her life. That is the reason why she is regarded as "inconsistent". Yet in this play she is not the only character who changes their mind. Agamemnon and Menelaus change too, even Achilles changes after Iphigenia's decision. They are not "inconsistent", because these changes are a piece of the dramatic economy:

${ }^{43}$ Siegel 1980: 311: Iphigenia realizes that "death is impossible to avoid since the force of the army is irresistible. [...] one of Euripides' purposes here is to explore the psychological result of violent, unreasonable and overwhelming political pressure on the mind of an innocent and naïve youth, whose will and natural desires run counter to the needs of the state". Iphigenia might indeed be impressed by the violence of the army, but the "needs of the state" are those of her father and homeland, so, if we take into account his explanation of 1255-75, there is no contradiction between Agamemnon's point of view and Iphigenia's monologue (1368-1401). 
the public should be prepared to see an innovative version of the well-known legend. Euripides gradually adapts the main characters to this new legend. Iphigenia, like the other Euripidean victims, gives her life because she loves this life. Otherwise, her sacrifice has no value at all.

Concerning Iphigenia's real or artificial change, and her free or constrained choice, first of all we think that there is no reason in the play to doubt the sincerity of her offer, since it continues Agamemnon's last arguments of 1255-75, and corresponds to the sacrificial victim's longing for posthumous glory. Neither is there any reason to introduce a constraint choice: Iphigenia is not Polyxena, Hecuba's daughter; she is not a slave but a free princess, her palace has not been destroyed, and, even if Agamemnon dies in war, her mother, brother and sisters will still remain alive ${ }^{44}$. There are indeed similarities between Iphigenia and Polyxena: their sacrifice is the demand of a powerful army (and deity), Ulysses plays an important role in this army, the two mothers, Clytemnestra and Hecuba, are unwilling to yield to the "necessity" of sacrificing their daughter. Yet in the Hecuba, Polyxena is a captive: her future would not be a princess' but a slave's life; she probably would be "purchased" by a "cruel master" (Hec. 359-60) and married to a "purchased slave" (Hec. 365-6) instead of the royal husband she deserves. Iphigenia is a free woman: there is no risk of losing her freedom or being married to a man of inferior social status. And hence freedom or marriage means less to her than paternal love or Hellenic pride. This is a personal, paternal, and patriotic choice, but a completely conscious one and a completely free one. Euripides emphasizes here the absurdity of war: it annihilates love for a father, a family or a country, in the name of love.

Before leaving the stage, Iphigenia, like a seer, prophesizes her future: she will be "saved" and her mother will "be glorious" ( $\varepsilon \dot{\mu} \mu \lambda \varepsilon \dot{c} \varsigma)$ because of this sacrifice (1440); no other "grave will be raised" for her (1442) than "the goddess' altar" (1444); she will be honoured as a "benefactor of Hellas" (1446). That is the reason why she presents demands to her mother, as if now Iphigenia were the commander to whom Clytemnestra shall obey (1460). A parallel can be stressed with Alcestis' unusual (or extravagant?) demands to Admetus in the Alcestis, namely not to remarry

${ }^{44}$ A comparison between Iphigenia and Polyxena in the framework of the study of human nature and the attitude toward death in Euripides: Czerwínska 2007: 114-123. See also Durán López 2003: 77-78. A comparison between Iphigenia in the $I A$, Iphigenia's sacrifice in the Aeschylean Agamemnon, and Polyxena in the Hecuba: Gödde 2011: 286-288. 
in order to keep her memory alive forever ${ }^{45}$. Iphigenia's demands are: first of all, no external signs of mourning (no hair cut, no black clothes 1437-8, 1448); secondly, the most difficult but also the most important, expressed

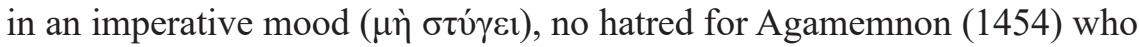
sacrificed his daughter "unwilling, for the Hellenic homeland" (1456). Given that Iphigenia's wishes will not be fulfilled, is this Euripidean innovation to be interpreted as an alternative to a violent myth $^{46}$ ?

Iphigenia's last words confirm her love for life, her willingness to acquire glory, her "paternal" and "patriotic" reasons to die. Nevertheless, Iphigenia remains a maiden who has to give up the idea of marriage and exchange it with sacrifice. That is the reason why she asks for a $\pi \alpha$ ióv (1468) and seems convinced that her blood will "blot out the oracles" (1485-6) ${ }^{47}$. Her last words also confirm the unity of her character: she abandons "the light" (1502, 1506-9), "the sweetest thing to look on", according to her previous words (1250); now she has strong reasons to do that, and does not "regret death" (1503), because she knows that she (i.e. the light: $\dot{\varepsilon} \theta \rho \varepsilon \dot{\psi} \psi \alpha \theta$ "

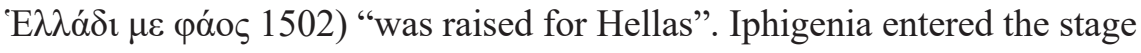
as a character on whom focus mortal gazes all around ( $\pi \varepsilon \rho i ́-\beta \lambda \varepsilon \pi \tau \circ \varsigma 429)$; she leaves the stage aspiring to immortal glory, and the Chorus' 1504 and 1531 confirm that ${ }^{48}$. Her sacrifice is not merely a ritual act or a substitute for marriage, it is the starting point of the new era of freedom for Agamemnon, released from guilt, for Iphigenia, released from her Aeshylean role as a passive victim, and for Hellas, released from the barbarian threat.

The end of the play, 1532sqq, is bracketed by Kovacs and is obviously "meant to bring the play into mythical agreement with the Iphigenia among the Taurians" 49 . Our purpose here is not to discuss authenticity: the $I A$ is certainly a "revised" or "re-written" play, so it is difficult to be sure that it was Euripides himself who wrote these lines, and not his son/ nephew Euripides minor or a later "reviser". To the purpose of our study, that makes no difference: Iphigenia's character is still indirectly present

${ }^{45}$ Concerning Alcestis' demands and Admetus' acceptance, see Bacalexi 2007: 15-17.

${ }^{46}$ Durán López 2003: 86 about the continuation of violence.

${ }^{47}$ The role of the $\pi \alpha$ ióv is examined by Gödde 2011: 278. See also Bacalexi 1993: 345 for the human and divine intervention.

48 Ací $\mu v \eta \sigma \tau o v 1.1531$ remains until now in modern Greek the epithet for the deceased.

${ }^{49}$ Kovacs 2002: 333. López Férez 2014: 164 refers to "scholars who exaggerated" in refusing the authenticity of some passages, though he seems not to disagree with those who regard the end of the play as spurious (173 and n.1212). 
(1552-60). Her last words, reported by the messenger, add nothing to her previous argumentation and change nothing concerning her previous motivation. Furthermore, we can imagine that the impact on the public does not really change because of Iphigenia's substitution by a hind (1585-95). What matters for one who knows the mythical Iphigenia and then sees her on stage is the capacity of the maiden to offer a solution to a major crisis: the one of the army longing for blood and war, the one of Agamemnon seeking to assume his duty as a military leader but remaining torn between this duty and his weak will, and, finally, the one of Greece, the "homeland" of freedom, on the threshold of a war of conquest. In order to accomplish her mission, Iphigenia must disappear qua Iphigenia, and be reborn as a "soldier of duty" 50 .

Iphigenia turned the sacrifice from a divine (i.e. irrational) demand to a human (i.e. rational) choice. Euripides' renewal of Iphigenia's character would not be enough to delete the ancient bloody myth of the Atreides whose issue is well known: Agamemnon's murder by Clytemnestra, Oreste's and Electra's revenge, the Erinyes tracking down Orestes, his final release after Athena's intervention, Iphigenia's exile among the Taurians and her longing to return home, her nostalgia. Nevertheless, the new Iphigenia is a successful one, because of the new elements introduced into the ancient legend. It is not a coincidence that this play has given inspiration to later imitations or transformations (e.g. the homonymous tragedy of Racine, or the film by Michalis Kakogiannis), and that it is one of the most performed Euripidean tragedies nowadays in Greece or elsewhere ${ }^{51}$.

Certainly, the ancient spectator's reactions remain unknown so one can only wonder how different they would be from ours. Despite Aristotle's negative judgement about Iphigenia's character as an example of unexplained change of mind, it would be hardly believable that the ancient public

50 Or as an "artist", following Luschnig 1988: 126-127.

${ }^{51}$ Michelakis 2006: 105-129 discusses the reception of the play from Antiquity until now, including the history of the text and a review of the main scholarly readings (generic, historical, cultural, social, or ideological). He notices that "the level of sophistication of the debate provides valuable insights into the world of $I A$ that 'straight' readings [...] inevitably miss" (119). We particularly recommend Michelakis' appreciation on Kakogiannis' Iphigenia (127-129); we would only like to add the director's reference to Cyprus: "my name is Michalis Kakogiannis; my country, Cyprus". This opening statement of the film puts forward the "pioneering reading" of the play connected with the history of the Eastern Mediterranean. 


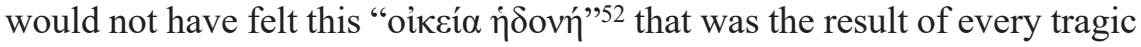
performance and is to be associated with tragic ká $\theta \alpha \rho \sigma t \varsigma$. Iphigenia is not an "ordinary" sacrificial victim; but are there any "ordinary" victims in Euripides? Alcestis, demanding Admetus' eternal mourning and widowhood, Polyxena, claming her superiority over the Greek leaders, Macaria in the Heraclides, dying for Athens, which is not her own but is the only one to offer hospitality to her family, Menoeceus, the young prince choosing death rather than life and protection as a host of one of his father's allies: none of them is an "ordinary" victim accomplishing a ritual or obeying an order. All of them operate a real metamorphosis of the sacrifice motif, they appropriate the theme but they present it as different from what is already known by means of their legend. Iphigenia's Euripidean legend is not an exception: the poet creates a new Iphigenia, merging all the previous ones. This is the reason for the play's success from Antiquity until now.

\section{Bibliography}

Bacalexi, C. (1993), La notion de noblesse chez Euripide : étude sémantique et thématique. Thèse de doctorat, Université de Paris-Sorbonne-Paris IV (microfilm).

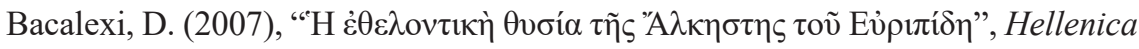
57 1: 7-28.

Bonnechere, P. (2009), "Le sacrifice humain grec, entre norme et anormalité", in P. Brulé (éd. par), La norme en matière religieuse en Grèce ancienne: actes du IXe colloque du CIERGA (novembre 2007). Liège, 189-212.

Crespo Alcalá, P. (2002), "Ifigenia: el sacrificio de una figura trágica" in F. De Martino i C. Morenilla (a cura di), El teatre clàssic al marc de la cultura grega i la seua pervivència dins la cultura occidental. 5, El perfil de les ombres. Bari, 85-110.

Czerwińska, J. (2007), Anthropeia physis come dramatis persona in Euripide. Łódź.

Denniston, J. D.-Page D. (1979), Aeschylus, Agamemnon, Oxford.

Durán López, $\mathrm{M}^{\mathrm{a}}$ de los A. (2003), "Ifigenia y la no violencia" in $\mathrm{M}^{\mathrm{a}} \mathrm{T}$. López Beltrán, $\mathrm{M}^{\mathrm{a}} \mathrm{J}$. Jiménez Tomé, E. $\mathrm{M}^{\mathrm{a}}$ Gil Benítez (eds.), Violencia y género: (acta del Congreso interdisciplinar sobre violencia y género, celebrado en la Facultad de Filosofía y Letras de la Universidad de Málaga los días 29

52 Tsitsiridis 2010: 59-61. 
y 30 de noviembre y 1 de diciembre de 2000, organizado por la AEHM/ UMA). Málaga, 1 75-87.

Felson, N. (2001), "Alienated couples in Euripidean tragedy: a Bachtinian analysis", in P. I. Barta [et al.] (ed. by), Carnivalizing difference: Bakhtin and the other. London, 23-50.

Foley, H. P. (1982), "Marriage and sacrifice in Euripides' Iphigenia in Aulis", Arethusa 15: 159-180.

Foley, H. P. (1985), Ritual Irony: poetry and sacrifice in Euripides. Ithaca.

Funke, H. (1964), “Aristoteles zu Euripides' Iphigeneia in Aulis”, Hermes 92: 284-299.

Gibert, J. (1995), Change of mind in Greek tragedy. Göttingen.

Gibert, J. (2005), "Clytemnestra's first marriage: Euripides' Iphigenia in Aulis" in V. Pedrick and S. M. Oberhelman (ed.), The soul of tragedy: essays on Athenian drama. Chicago (Ill.), 227-248.

Gödde, S. (2011), Euphêmia: die gute Rede in Kult und Literatur der griechischen Antike. Heidelberg.

Goossens, R. (1962), Euripide et Athènes. Bruxelles.

Hall, E. (1991), Inventing the Barbarian: Greek self-definition through tragedy. Oxford.

Jouan, F. (1983), Euripide. 7, 1: Iphigénie à Aulis. Paris.

Kovacs, D. (1999), Euripides, Trojan Women, Iphigenia among the Taurians, Ion. Cambridge.

Kovacs, D. (2002), Euripides, Bacchae, Iphigenia at Aulis, Rhesus. Cambridge.

López Férez, J. A. (2014), Mitos en las obras conservadas de Eurípides: guía para la lectura del trágico. Madrid.

Loraux, N. (1985), Façons tragiques de tuer une femme. Paris.

Luschnig C. A. E. (1988), Tragic aporia: a study of Euripides' Iphigenia at Aulis, Berwick Vic.

Mellert-Hoffmann, G. (1969), Untersuchungen zur Iphigenie in Aulis des Euripides. Heidelberg.

Michelakis, P. (2006), Euripides: Iphigenia at Aulis. London.

Michelini, A. N. (1999-2000), "The expansion of myth in late Euripides: Iphigeneia at Aulis", ICS 24-25: 41-57.

Nussbaum, M. C. (1986, rev. ed.), The fragility of goodness: luck and ethics in Greek tragedy and philosophy. Cambridge 
O’Connor-Visser, E. A. M. E. (1987), Aspects of human sacrifice in Euripides. Amsterdam.

Rehm, R. (1994), Marriage to death: The conflation of wedding and funeral rituals in Greek tragedy. Princeton.

Said, S. (1984), “Grecs et Barbares dans les tragédies d'Euripide: la fin des différences?", Ktèma 9: 27-53.

Sébillotte Cuchet, V. (2006), Libérez la patrie! Patriotisme et politique en Grèce ancienne. Paris.

Seaford, R. (1987), “The tragic wedding” JHS 107: 106-130.

Siegel, H. (1980), "Self-delusion and the volte-face of Iphigenia in Euripides' Iphigenia at Aulis", Hermes 108: 300-321.

Siegel, H. (1981), “Agamemnon in Euripides' Iphigenia at Aulis" Hermes 109: 257-265.

Stahl, H. P. (2003), “On 'extra-dramatic' communication of characters in Euripides" in J. M. Mossman (ed.), Euripides. Oxford-NY: 122-138.

Stockert, W. (1992), Euripides, Iphigenia in Aulis. Wien.

Rosenbloom, D. (2011), "The panhellenism of Athenian tragedy”, in D. M. Carter (ed.), Why Athens? A reappraisal of the Athenian politics. Oxford-NY, 353-382.

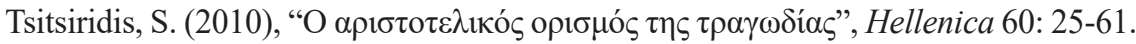

Tzanetou, A. (1999-2000), "Almost dying, dying twice: ritual and audience in Euripides' Iphigenia in Tauris”, ICS 24-25: 199-216. 